\title{
Spreading the Word: \\ Feminist Print Cultures and the Women's Liberation Movement
}

\section{Laurel Forster}

This article investigates the significance of print cultures to women of the second wave of feminism. It takes a broad view of a male-dominated publishing industry and highlights the various ways that women intervened and responded through their writing, publishing and organisational skills and political commitment. It discusses the shifts in female publishing cultures, emboldened by the overarching Women's Liberation Movement and empowered through the establishment of separatist networks. Feminist activism, I argue, may be discerned in the impetus behind the construction and publication of feminist magazines. The last section considers the different publishing hinterlands of three feminist magazines, overlapping in their concerns, but distinctive in their approaches: Shrew, Spare Rib and Womens Voice, and argues that such magazines of the second wave represent the diversity and print activism of the WLM.

The significance of the printed word to the Women's Liberation Movement (WLM) of the 1970s can hardly be overstated: Marsha Rowe recalled that, 'suddenly words were possible', and Lynne Segal remembered the output of 1970s feminism as an 'explosion of creative work from women ... fiction, publishing, poster-making'. ${ }^{1}$ The second wave of feminism, unlike the present fourth wave with a range of online media at its disposal, ${ }^{2}$ was dependent upon the written word: 'We ate literature' recalled Bea Campbell, discussing her consumption of feminist reading. ${ }^{3}$ This newly-found empowerment was not only about women's writing, in itself described as ‘an act of power’ by Sara Maitland, ${ }^{4}$ but also achieving access to, and control over, the production and publication of women's writing: creating an autonomous 
publishing space for women so that, unlike previous generations of writers, the 'Queen' no longer had to 'sound like the King'. ${ }^{5}$ Women's affinity to print was unquestionable: ${ }^{6}$ long in evidence through tracts, novels, pamphlets, periodicals and more, all concerned to augment, bolster and advance the cause of women in diverse ways. Feminists of the second wave did much to recover and reprint the long history of female writing, demonstrating that the written word was a dominant mode for individual testimony, creative cultural expression, and a vehicle for group campaigning and political dissemination. Earlier feminist writing was both a valued legacy in the second wave and a conduit for new generations of feminists to learn from feminist foremothers. However, at the WLM's resurgence of feminist consciousness and intent in Britain in the late 1960s and 1970s, control over the printed word, and its production, was seized upon as a potential portal to power.

In particular, the 'experience of production' was highly valued as a feminist activity. ${ }^{7}$ If print was the means of spreading the word, then engagement with the publishing industries or print cultures demonstrated participation in the cause of women's liberation. This paper argues that engaging with the material conditions and processes of print culture may be understood as inherently part of the feminist struggle. In addition to drawing attention to important pressing social issues, feminist participation in print cultures also concerned the right to participate and construct the very means of communication: the production of the written word. If 1970s feminism is deemed to be 'the real thing: an age of activism', ${ }^{8}$ then not only was print and publishing a crucial form of activism with manifold points of intersection and contributions to the women's liberation cause, but production of a feminist magazine, one of the movement's most popular forms of print media, was an achievable way of bringing different political identities and hinterlands, as well as women's diverse skills, to political effect. Consequently, magazine production as activism enabled women to both participate in 
the movement and explore their own particular feminist politics. Spreading the word through feminist print and publishing cultures of the 1970s became both personal and political.

In the WLM in the UK (and elsewhere), there were deeply meaningful shifts in women's relationship with print cultures and related activism which, like other political activity, involved struggle, argument and difficult decisions. Feminist print cultures, though, were pulled divisively: they had to engage with industry requirements and procedures, i.e. the man's world of publishing; whilst also expressing often radically oppositional and newly emergent articulations of feminism. It was both of the world of print, i.e. the public sphere, and a separatist activity. Involvement in the publishing industries, including printing and bookselling, was seen in itself as an opportunity for feminist commitment and activism. This may be witnessed by the number of feminist publishers and printing organisations that established at this time. This article will outline the scope of the diverse engagement of the WLM and its members with the publishing industry, drawing upon feminist histories of print cultures, personal testimonials and critical writing on magazines. This will lead to three contextualised examples of feminist magazines which emerged out of second wave print cultures: Shrew (1969-1974), Spare Rib (1972-1993) and Women’s Voice (1972-1982). These magazines, with overlapping content, and of the same moment and movement, emerged out of different circumstances of production and engagements with feminist print cultures.

\section{A diverse engagement with publishing cultures}

The diversity of feminist forays into print, publishing and associated industries is currently receiving detailed interdisciplinary critical attention, crossing boundaries of literature, cultural studies, industry analysis, book history, social movement theory and gender politics. Feminist engagement with publishing history sees women variously as objects, subjects, critics, participants and producers, and so extends to: the role of feminist bookshops and 
booksellers; the history of feminist book publication; women's intervention across the range of printing and publication skill sets; feminist publishers; and of course feminist print media artefacts. Simone Murray, in her important study, has argued that this interdisciplinarity has affected the study of women's broader relationship to print, noting that feminist publishing history has formerly been ignored because it has fallen between two disciplines:

too literary in its associations to be annexed to feminist cultural studies; and too tainted with commercialism to fall within the purview of literary criticism. ${ }^{9}$

Trysh Travis has noted a further problem: 'this canon of what we might call a feminist book history concentrates primarily on women readers and authors, not on the workings of the communications circuit that transforms manuscripts into books and brings them to market.' Travis continues: 'The desire to document women’s presence in the book trades has meant that attention to gender as a form of power has usually been limited to noting that the trades were male-dominated. ${ }^{10}$ However, in relation to magazine production at least, critics are making important connections between gender politics and print artefacts: 'More than instrumental tools, rituals or resources for mobilization, Greenham women’s cultural artefacts and communication practices were the very means by which their politics garnered shape and meaning. ${ }^{11}$ Feminist activism, then, may be discerned in the specific detail of female groups and individuals, and their very engagement with and utilisation of print. ${ }^{12}$

1970s feminist publishing is difficult to generalise precisely because of its small scale and diverse nature. As movement rather than organisation, ${ }^{13}$ the WLM consisted of local gatherings, collectives and some individuals with high profiles. Feminist print cultures emerged from the 'small group' politics of the UK WLM. ${ }^{14}$ Some groups and collectives were formal, some casual, frequently they suffered a shortfalls of funding and adequate premises, yet each operated to its own agenda with variable affiliations to the movement. Each contributed differently to feminist publishing, understanding feminism differently and 
expressing that specific mode in print. Groups were neither always wholly separatist, nor always entirely in sisterly accord, and they variously reacted against, and yet also relied upon, the mainstream press. Feminist print cultures have always had relationships with other kinds of publishing organisations, ${ }^{15}$ and interventions into the male-dominated professions of printing and publishing were neither straightforward nor unproblematic for women. The point of similarity was to bring all manner of women's expression to print, and the feminist activism may be discerned in intention and experimentation, in the giving of time, energy and commitment to a practical claiming of the means of production of women's words. A consistent intention was to build a feminist publishing industry aligned with feminist principles, often resulting in complex negotiations with, or attempted total rejection of, extant publishing practices. Thus the notion of independent publishing emerged: 'In 1970s discussions of feminist publishing, the concept of the women-only forum is expanded into that of a "women's independent communications network."'16 For some, this developed into separatist formations with the 'political necessity of women controlling all aspects of the publication process' so that the hostile male press could be shunned. ${ }^{17}$ Hence, 'the central perception with which feminist publishing originates: that production of the printed word and its interpretation constitute forms of political power. ${ }^{18}$ This separatist seizing of publishing power was of central significance: for example, of Trouble \& Strife, a feminist magazine with separatist underpinnings, Cameron and Scanlon state: 'No man ever contributed to $T \& S$ as an editor, writer, designer, typesetter or illustrator; the only men it dealt with were those it paid to print and distribute the magazine.' ${ }^{19}$

Furthermore, Trysh Travis has described how the US Women in Print movement (WIP) gained strength as a reaction against the publishing industry's sexism and gender hostility . This separatist feminist organisation assembled women working, or wanting to work, in the publishing industry, intending to provide industry training and create its own 
network of readers, writers, editors, printers, publishers, distributors and retailers, and construct its own printing industry duly hostile to the male publishing industry. ${ }^{20}$ It was hugely supported by the energies of lesbian women also seeking a print culture of their own. ${ }^{21}$ The first WIP conference (1976) imparted publishing skills and gender politics with the dual aims of increasing women's skills in the printing world, and of creating a feminist print network to counter the male network, proven untrustworthy and undermining to women publishing in the 1960s. ${ }^{22}$ It was not that trade publishers were not taking feminism seriously by the 1970 s , but that feminist intentionality was to undermine patriarchal capitalist control of feminist writing, ${ }^{23}$ and by 1979 a similar 'Women in Publishing' movement (WiP) had started in London. ${ }^{24}$

Personal testimonials from some women working in the publishing industry at the time reveal complex relationships between their feminism and their publishing work. In Chester and Nielsen's In Other Words, one editor asks 'What the Hell is Feminist Editing?' and concludes that it implies careful selection and nurturing of important female texts to which only a specifically feminist publishing house would allocate time and resources. ${ }^{25}$ Commitment to feminist writing was strong, with one feminist writer becoming involved in publishing out of sheer 'belief in the worth of the writing', ${ }^{26}$ and other women who viewed their writing as their most important work, but used those same skill sets in mainstream publishing to earn a living through, say, copy editing jobs. ${ }^{27}$ Gail Chester, whose 'employment in publishing began as a political act - [her] desire to see radical literature of all types more widely available', still after eighteen years felt herself to be 'on the outer fringes of the profession', perhaps because of her politics, class, ethnic origins or because, as she puts it, of 'being an uppity woman'. ${ }^{28}$ For other feminist writers and publishers, independence was not so unambiguous: Outwrite feminist magazine, intended to voice 'Black and Third World women's struggles', whose founders successfully published with only 'few technical skills 
(initially)', was dependent upon Greater London Council funding as well as the activism and militancy of a movement. ${ }^{29}$ Feminist activism in print and publishing, whilst some strove for separatist status, was also subject to important dialogical relationships with a number of industries and agencies, rarely seen as innocent of associated connections and processes.

\section{Women's Liberation and the mainstream and underground presses}

The relationship of feminists to the presses is complex and varied, with surprising contexts that sometimes belie straightforward assumptions. ${ }^{30}$ And production of a feminist magazine always implied some relationship to other forms of print production, even if total opposition. Overall, the WLM's relationship with the daily press was complex, having been described as 'tangled and uncomfortable'. ${ }^{31}$ Juliet Mitchell has discussed how the media divisively set different WLM groups against each other, resulting in a national regulation that 'each group could describe its own politics to the press, etc. but not those of other groups' ${ }^{32}$ Despite the 1970 formation of the Women in Media Group, which aimed to improve the situation of women in journalism, broadcasting and publishing, and the reporting of women's issues, such policies caused hostilities and some felt that this 'left reporters with few options but guesswork, caricature or silence on feminist issues'.33

However, it is possible to over-simplify the representation of gender in the press, ${ }^{34}$ and critics of second wave feminism have problematised the relationship of the press to second wave feminism. Kaitlynn Mendes, applying critical discourse analysis to articles on feminism from the long 1970s, has studied representations of feminists in US and UK national daily newspapers. Mendes argues that, 'it is difficult to make overall, conclusive remarks on news coverage other than to say it was fragmented and contradictory-newspapers simultaneously portrayed the movement as effective and serious and ineffective through trivialising feminists and their concerns., ${ }^{35}$ This contrasts somewhat 
with other discussions that claim more negative news coverage, however Mendes did find the Daily Mirror ‘consistently constructed the women's movement and feminists as de-legitimate and deviant'. ${ }^{36}$ Overall, Mendes argues that, 'there was far more legitimising or supportive coverage than previous scholars have claimed, and that these articles frequently engaged with the movement's members, their goals, and constructed it as unified, good for women, necessary, and liberating. ${ }^{37}$ Mendes' findings lead her to suggest that the US movement 'formed highly organised groups [...] whose members understood the journalistic conventions needed for attracting the media', whilst, 'Conversely, the UK movement tended to consist of smaller, more fragmented groups, who either made little or no attempt to attract mainstream media attention, or who actively opposed it. ${ }^{, 38}$

However, this unevenness in mainstream representation does not imply that the underground press was more consistently sympathetic or harmoniously attuned to women's rights and/or feminist expression. Elizabeth Nelson describes ways in which 1960s underground magazines failed to take the WLM seriously: IT magazine, she suggests, remained ‘committed to sexism' and certainly 'did not grapple with the issues raised by women's liberation'. ${ }^{39}$ Friendz, 'had it both ways on the question of women', but saw women's liberation as a joke; and at least $\mathrm{Oz}$, 'did seem to understand the necessity to move beyond tokenism with regard to women and their struggle'. ${ }^{40}$ Discussing conflict networks and 1960s political movements, Carol Mueller identifies similar dissatisfaction with the 'low status' women experienced, despite their high levels of education, in the 'submerged networks of civil rights and the New Left' ${ }^{41}$ Marsha Rowe, who worked for $\mathrm{Oz}$ and Ink, recalls the role of women in the underground press: 'The women who worked on its magazines and newspapers served the men and did the office and production work rather than any editorial work. ${ }^{42}$ Rosie Boycott, who worked for Friendz and co-ordinated the woman's issue, was more explicit about the attitudes of the underground press men: 
The underground press had an ambivalent attitude towards women. "You can fuck anytime, but ask a girl to make Ovaltine?" Oz editor Richard Neville was quoted as saying. He was almost right. Going to bed, or, as the cliché had it, getting laid on the back copies, was expected. To refuse was both oldfashioned and hypocritical in a culture promoting free love. ${ }^{43}$ Boycott explains the ambivalence of editors of International Times, Britain’s oldest underground paper, while condemning the Miss World competition: 'The editors could sigh complacently because they weren't subjecting their girlfriends to parading in swimsuits round the Albert Hall. But they weren’t encouraging them to become editors or reporters either. ${ }^{44}$ Nonetheless, the counter-cultural and anti-establishment stance of 1960s underground presses in Britain and elsewhere was an important precursor to the print media of the UK WLM: it provided a platform for oppositional politics and a training ground for writing and publishing.

Despite the underground press’s sexism, its informal structures and compressed way of working permitted those women involved in various magazines, such as Sheila Rowbotham on Black Dwarf and Germaine Greer on Suck, ${ }^{45}$ closer proximity to the printing and publication processes, and an introduction to the industry. They may have railed against the sexism, but women such as Rowbotham, Boycott, Rowe, Greer used those industry skills for the feminist cause, some producing ground-breaking writing and journalism. ${ }^{46}$ For Marsha Rowe at $\mathrm{Oz}$, the political mismatch between the 'sex-objectifying images' and the ideals of women's liberation caused her to 'feel contradictions exploding inside my head, ${ }^{47}$ and led to her jointly establishing Spare Rib with Boycott:

This was prompted by all we had learned on the underground press, which included the notion that self-organizing was possible, as well as familiarity with the mechanics of production and distribution. Rosie had some journalistic experience on Frendz, while my editorial experience was limited to research and helping on layout. ${ }^{48}$ 


\section{The emergence of feminist print cultures}

A varied and often problematic relationship existed between women of the WLM, and its emergent publishing cultures, and the existing publishing and press industries. Whether feminists rejected the male press industry totally or saw it as a training ground, at the very least there was suspicion caused by gender-hostility and a desire to claim the printed word for the feminist cause. The development of feminist presses became crucial to the dissemination of feminist communication, even being regarded as instigators of social change. ${ }^{49}$ They also performed a crucial role in their work of recovery, unearthing and reprinting feminist texts. Feminist publishing houses, such as Virago and The Woman's Press, were also often more successful in both financial outcome and public recognition than other feminist media production such as feminist film or feminist magazines. ${ }^{50}$ Often having to weave a difficult path between political authenticity and commercial viability, they persevered, feeling it was a 'duty' to survive. ${ }^{51}$ The relationship of feminist presses to other industry sectors imposed difficulties, such as when Virago (1973) was compelled to print very small hardback copy runs just to achieve journalistic reviews. Murray discusses complex industry engagements, certainly in the case of Virago, where business acumen, regular hierarchical management and an instinct for survival vied with feminist activist ambitions and a desire to run women's publishing differently. ${ }^{52}$ Murray describes 'the duality of [Virago's] self-conception: it perceived itself simultaneously both as a commercial publishing house and as an intrinsic part of the British women's liberation movement. ${ }^{53}$ Indeed, writers for Virago have described a different publisher-writer relationship. ${ }^{54}$ Catherine Riley has argued that Virago intended to change constructions of gender through the content of its literature and by influencing and expanding the literary landscape. ${ }^{55}$ The history of financial pressures, takeovers and industry dealings of the feminist presses is evidence of a range of approaches to the commercial interface of this feminist expression and activism. 
Important contributions were also made by booksellers to feminist print cultures and the dissemination of the feminist printed word. For instance, in the US, the Feminist Bookstore Network was run by the owner of Old Wives Tales bookstore, Carol Seajay. The Feminist Bookstore Newsletter (1976-2000), designed to enhance communication amongst fellow feminist booksellers, was described as the 'industry bible for lesbian and feminist booksellers'. ${ }^{56}$ Feminist scholarship has discussed the important contributions made by bookstores to the WLM, seeing these women-centred, and sometimes women-only, spaces as feminist meeting places and political entities in themselves. Kristen Hogan argues that from as early as 1970 onwards in the US, bookstores provided public spaces for feminism: 'Different from the leftist and progressive bookstores of the 1960s, the feminist bookstore created an entirely feminist space that provided a context for the publications on its shelves; this more specific collection allowed for broader attention to women's literature and uniquely emphasised the existence of a body of feminist literature. ${ }^{57}$ Hogan follows Nancy Fraser’s argument for feminist bookshops as well as journals and publishing companies, seeing them as Habermasian public spheres, part of a 'feminist subaltern counterpublic' which function both as 'spaces of withdrawal and regroupment' and as 'bases and training grounds for agitational activities directed towards larger publics’ ${ }^{58}$ Feminist bookstores then, have been seen as an essential resource, circulating mimeographed and Xeroxed copies of otherwise unavailable texts, republishing out-of-print books and operating as libraries with readers studying 'store copies' in situ. Hogan describes bookstores as being closely associated with lecturers and students on women's studies courses, as places where academic and community feminism continued to influence each other, organising and distributing feminist texts, acting as primers for women's studies courses, and offering places for connections and 'collective power'. ${ }^{59}$ Thus, feminist bookshops were involved in education as centres themselves, but also in alignment with formal education courses in women’s studies. ${ }^{60}$ 
In the UK, the well-known, and local council-funded, Silver Moon bookshop opened in 1984 on the Charing Cross Road, London, founded by Sue Butterworth and Jane Cholmeley; eventually taken over by Foyles in 2001; like its American counterparts becoming a centre for feminist information and resources, selling books and magazines unavailable elsewhere. It fulfilled different kinds of feminist work including promoting feminist authors, publishing, producing its magazine, Silver Moon Quarterly, and helping victims of abuse find refuge ${ }^{61}$ Thus its connections and activism extended beyond commercial transactions to the local community, the council and the world of feminist publishing. Regional bookshops also offered opportunities for local activism. Jill Radford, in discussing the Winchester Women's Liberation Group, describes how,

With women from one of the Southampton women's liberation groups and the Ecology Party, we transformed an SWP bookshop into a community bookshop to enable us to begin to acquire the emerging feminist books. October Books — its name never changed — is still trading as far as I know and remains the one alternative bookshop in the area. ${ }^{62}$

Lucy Delap discussed ways in which feminist bookshops were 'nodal' points in a disparate WLM, combining community and commercial spaces, even suggesting a WLM Bookbus to provide feminist education for rural women. ${ }^{63}$ However the history of the bookselling business is a ruthless tale and inevitable difficulties of the crossover between feminism and competitive commercialism have led to arguments that Silver Moon eventually put Sisterwrite (1978-1986), a neighbouring feminist bookshop with an international reputation, out of business. ${ }^{64}$

The circulation of feminist ideas through print media, including written testimony in the form of personal exposés of sexual inequalities, writing by women of colour and by women who felt marginalised by society, feminist fiction, historical recovery and criticism, discussions in the daily press, feminist presses and women working in publishing, and the 
very act of selling feminist books and magazines — all became hugely important aspects of the WLM. Even placing a book with a non-feminist publisher could cause discussion and debate. However, whilst some women were becoming well-known for their writing, ${ }^{65}$ or worked towards a feminist press, others expressed their commitment to the WLM through the more modest writing and publishing of a feminist magazine.

\section{Feminist magazines}

The scope of women's involvement in print in the 1960s and 1970s provides a crucial context for understanding the diversity of WLM magazines. Second wave feminism emerged from a complex set of social circumstances and an array of political, counter-cultural, antiestablishment and socialist movements. Reflecting this diversity, many small feminist groups across the UK, as well as Europe, ${ }^{66}$ had their individual magazines and newsletters, each proffering specific interpretations of feminist engagement. ${ }^{67}$ Similar to the suffragette papers, feminist magazines of this later period had to both inform and entertain existing memberreaders, whilst spreading the word of the feminist cause to men as well as women. ${ }^{68} 1970$ s feminist magazines adopted and adapted the print media form hijacked decades earlier by multinational corporations peddling oppressive capitalist femininities. Indeed, the female oppression evidenced by domestic magazines, so effectively brought to attention by Betty Friedan in the $1960 \mathrm{~s},{ }^{69}$ is one of the aspects of women's lives strongly attacked by the WLM magazines. These feminist magazines offer a much broader view of women's lives and occupations including housewives, working women, mothers and single women, and mark a huge range of issues, personal and political, from female sexuality and childrearing to women's refuges and improved rights for night workers. ${ }^{70}$ They bring history to bear on current issues, reminding readers of previous feminist campaigns and campaigners; report upon events and activism on national and local stages; provide space for individual expression; air debates, share humorous observations and build a feminist culture. They 
reveal multiple feminisms based in different strands of philosophical and political thought, belying any sense of a singly-focussed second wave of feminism.

In addition to diverse content, feminist magazines are also varied physically, ranging from home-typed newsletters, often Xeroxed and stapled, assembled by small consciousnessraising collectives and intended to circulate information within a single-focus group, to publications that in some ways emulate, in content or appearance, more commercial, even feminine domestic magazines. ${ }^{71}$ Some magazines had wider, even national, distribution, and some carried feminist-attuned advertisements to generate income, similar to more commercial offerings. ${ }^{72}$ The varied tone and appearance indicates that, whilst some magazines had clear political affiliations, others were purposefully open to ranges of opinion. All had in common the pursuit of women's liberation and were instrumental in spreading a diverse set of messages about feminism and gender inequalities.

Membership of a magazine-producing feminist group meant involvement in an allfemale enterprise where women could exercise full editorial control over the content, impossible in other in other media productions. ${ }^{73}$ A crucial mode of expression of second wave feminism, feminist magazines offered a voice not just to professional writers, feminist historians and academics, but significantly gave access to the printed word and opportunity for sharing experiences to women who were accustomed to having no voice. The processes of collectively producing, writing and publishing was a feminist commitment, and as much activism as other forms of consciousness-raising, ${ }^{74}$ offering a route to consciousness-raising through participation, expression and discussion, as well as political identification with the greater movement. As Cameron and Scanlon state: 'The magazine was an important part of our political and intellectual lives; it also made a unique contribution to the life of feminism in Britain. ${ }^{75}$ 


\section{Shrew}

Shrew (1969-1974) was the unaligned output of a wide range of different women's groups from within the London Women’s Liberation Workshop. It was produced by each group in turn, taking on responsibility for the theme of the whole magazine, its contents, layout, illustrations and design. Initially there were only four groups but, as the number of groups grew, a rotating editorship became more difficult; ${ }^{76}$ and by 1971 groups had expanded to forty-four plus four special interest groups. With a circulation around 5000, it was produced several times a year and only available through feminist bookshops such as Silver Moon, therefore circulating within those feminist public spheres already created by bookshop spaces, it appealed to an already-converted audience. Most issues have an alternative, but far from amateurish feel, including hand-drawn and handwritten sections, with items squeezed together on some pages. Individual testimonials lend a personal tone, alongside broader feminist rationale. As each collective had free rein over the magazine they produced, the look and content varies enormously. Some issues focus upon general themes under widespread feminist scrutiny, such as the family, women and work or the plight of women night cleaners. ${ }^{77}$ Different workshop groups with particular interests, however, had opportunity to reflect their own feminist direction and priorities within their issue: there was Psychology Shrew produced by the Psychology Group of the Women's Liberation Workshop, providing perspectives on therapies from psychotherapists, individual patients and groups; and Goodbye Dolly, the children's book issue assembled by the Women's Liberation Literature Collective and the Leeds Group. ${ }^{78}$ In production of this magazine as a mode of feminist expression, some groups took the opportunity to express a distinctive feminism as part of a diverse movement. Each women's liberation group had their own circle of members and operated to their own agendas, they were united by overlapping concerns of gender inequalities and 
women's rights, but many had their own distinctive approaches, political affiliations and interactions with the WLM.

One particularly focussed issue is ‘Goddess’ Shrew (Spring 1977) produced by the Matriarchy Study Group (several of whose members were also involved in the Alternative Socialism group), which was concerned with feminist theology and studying ancient religion and culture. This issue is devoted to explaining Goddess theology, with each article and illustration elucidating a different aspect of Goddess philosophy and beliefs. The issue opens with the introduction, 'Beyond Patriarchy', by exploring and explaining the basis of the Matriarchy Study Group collective, providing an account of their belief in control of the spirit and the influence that this could have on women's oppression of the moment. Explaining that the group came together 'Because several of us already had observed evidence for a previous universal Goddess religion' and seeing this issue as work-in-progress, the main aim is to share their work:

1. We want to share with other women our growing confidence that women have not always been "inferior", subject and oppressed by men in their families and in society. There was a time, universally, it seems, from the beginning of the human race until from 5,000 - 2,000 B.C. where everyone took for granted matriarchy values and society was organised on the basis of woman-led culture. The Goddess was worshipped not only in terms of fertility and survival but as a way of life in which the feminine, and female, were considered pre-eminent. Great civilisations were built in these cultures. ${ }^{79}$

Articles range from joining a matriarchy study group, to women's spirituality and sexuality, and they embrace ancient Egypt and fertility control, the Bible, priestesses, the moon, stone circles, tress and energy lines. The issue also contains poetry and suggestions for further reading, all illustrated with black, white and shaded line drawings of characters, objects and symbols. It is interesting, detailed and diverse. 
This issue of Shrew was an important first publication for the Goddess activist and feminist theologian 'Asphodel' (Pauline Long 1921-2005), ${ }^{80}$ whose feminist spirituality is seen in the contexts of Marxism, feminism and women's sexuality. ${ }^{81}$ One article on Women's Sexuality, signed by 'Pauline', explains that 'Return to knowledge of the Goddess has meant for women, confidence in their own sexuality as part of the world of nature, of intellectual endeavour, of progress to better forms of society.' and extends the discussion to 'the Women's Movement today'. ${ }^{82}$ Goddess Shrew, Daniel Cohen observes, alongside a painting exhibition, 'marked the beginning of the Goddess movement in the British Isles' ${ }^{83}$ Monica Sjöö, now well-known for her oil painting 'God Giving Birth' (1968) based on her own birth experiences and her belief in the Great Mother, wrote an article for the issue. Her project to understand ancient 'Womencultures', which link the subconscious to the Cosmic Mother, made expansive connections between, 'the Shaman's rebirth in the cave (the womb of the Mother), the Dead, the Earth's serpentine magnetic force ruled over by the phases of the Moon, the ancient Stone circles and underground chambers, divination, prophecy and oracular sleep. ${ }^{.84}$

As a feminist magazine of the second wave, this issue of Shrew engages with a specific feminism and represents the belief systems of a particular group. The impetus behind the magazine’s production comes from a small collective, and consistently reflects that particular group’s convictions, interests, politics and world view. The flexibility of the magazine format enables a varied and lively presentation of the Matriarchy Study Group, part of the wider WLM, but with its particularised framework for understanding women’s oppression. In this way, Shrew gave different London area collectives a platform from which to explain their brand of feminist politics, explore their own rationale, engage in consciousness-raising, situate their intersection within the WLM, and perhaps to garner interest and new members. 
Shrew offered an opportunity for independent self-representation through print and publication: publication was its activism. Importantly, this enabled a means of working independently from the established media, with its own channels of communication, and intending to 'give as many women as possible the experience of producing a journal'. ${ }^{85}$ Consequently, and unlike mainstream, commercial magazines, the production of Shrew can truly be seen as a collective effort, reflected in the multiple and varied voices within the different editions. Such variety and scope in expressions of different feminist themes were all accommodated under the umbrella of women's liberation at the time.

Helen Graham has suggested that Shrew could use its position as an 'external' publication (as opposed to the London Women's Workshop Newsletter which addressed women already identified with Women's Liberation politics), as a 'communicator' and offer a space for the exploration of identities. ${ }^{86}$ Reflecting upon ways in which identity exploration in Shrew might have shaped the way women thought about doing politics, Graham identifies the problem of both recognising difference and of joining in the activist political agendas of others:

The writers in Shrew are grappling with these problematics: recognising difference without solidifying it as difference and creating a politics not based on activist identities, but still evoking a 'we' that can reach out to 'anyone else'. ${ }^{87}$

Graham suggests that Shrew members, finding it reductive to make women a 'cause', saw communication 'as an end in itself', where involvement in the production of Shrew could be seen as 'action' both in the material production of the physical magazine and in the more esoteric, and politically important, assimilation of ideas and raising of consciousness. ${ }^{88}$ In drawing attention to prioritising the experience of production, Graham identifies the links between communication and activism, where the 'process is all'. ${ }^{89}$ Shrew was the forum for 
women to work through their identification with the movement and to participate in print activism in the very production of the magazine.

\section{Spare Rib}

Similarly to Shrew, Spare Rib (1972-1993) sought to bring the unequal position of women in British society to attention, also focussing upon female identity and female liberation, women and work, campaigns for working women, and debates about the family, raising the consciousness of British women during the second wave of feminism. However, in contrast to Shrew, Spare Rib emerged out of quite different publishing circumstances. Spare Rib, with print runs of 20,000, perhaps 100,000 readers at its peak, ${ }^{90}$ and national availability through WH Smith newsagent chain, has become the best-known feminist magazine of the second wave, always produced with the intention of reaching a national audience. Although Spare Rib has been criticised for not reaching out to women of all ethnicities and classes, especially in the first few years, ${ }^{91}$ in fact it is remembered as the magazine that over its lifetime most prominently represented the WLM. Its digitisation by the British Library (2014) will undoubtedly lead to further scholarship on this important magazine. Such was its impact that recent fourth wave online publications, ezines, feminist web pages and blogs have flattered the original by trying to emulate its sparky, humorous and insightful style, with the short-lived Feminist Times (2013-2014) discussing resurrecting 'old Spare Rib' by trying to use the same name. ${ }^{92}$

Spare Rib's presentation demonstrates it emerged from women with more professional understanding of publishing than many feminist magazines. Rosie Boycott and Marsha Rowe, with their experience from Friendz, Ink and $\mathrm{Oz}$, gathered a group of women to set up Spare Rib. ${ }^{93}$ The magazine emulates many of the characteristics of more conventional women's magazines, but does so with feminist intent and an openness not 
possible in a more commercially-oriented publication. The opening editorial letter, for instance, positions the magazine as open to commentary from the readership and, indeed, many personal testimonials were included. In some ways Spare Rib covers similar terrain to other, more commercial, women’s magazines, but approaches beauty, fashion, cookery and DIY handicrafts from a feminist-consciousness perspective, chiming with anti-capitalist feminism, and the anti-consumerist ethos of a 1970s lifestyle. Spare Rib's early foray into the world of commercial advertising, in order to support the magazine financially, was highly selective. ${ }^{94}$ Joanne Hollows has discussed the complex relationship of feminist magazines to commercial advertising, suggesting that Spare Rib, influenced by the counterculture, 'imagined "consuming differently"'. ${ }^{95}$ Further difficulties arose in combining professional publishing skills, industry know-how and professional contacts with feminist commitment. Disagreements arose over a sufficiently feminist tone, and arguments ensued between Boycott and Rowe about their different approaches to journalism and feminism, with Boycott giving more time to journalistic gatherings and press parties, and Rowe to feminist groups and conferences. ${ }^{96}$

Nonetheless, the combination of professional journalistic skills, an understanding of the publishing world, alongside the practical know-how of running a successful magazine, enabled a magazine with wide appeal and high-level content to be produced from the very first edition. Spare Rib, through its inclusive style, is a fine exemplar of the breadth of approaches to feminism available to women in the early 1970s. Traditional women's interests, especially in early issues, are presented in a way that demonstrates freedom from the masculinised world of manufacture and instead offers a counter-politics of female artisanal protest and subversion of commercialism with domestic crafts and DIY projects. ${ }^{97}$ This folk feminism represents an adaptation of domestic skills and crafts, such as the 'hippy love of embroidery', into a personal and political commentary on enforced domesticity and 
femininity. ${ }^{98}$ Spare Rib also had a 'News Section' which emulated the newspaper-style column layout and reported the work of local groups and the progress of national feminist campaigns. There were regular consciousness-raising features concerning body and mind, and there were more politically-oriented articles that explore and explain feminist issues of national concern. Alongside this is a more liberal-feminist strand, seeking to educate the reader about feminist histories and feminist perspective on ranges of topics like the workplace and the media. This breadth of content and approaches to feminism undoubtedly accounts for the early and sustained success of Spare Rib, maintained even after changes in its running and outlook. ${ }^{99}$

Spare Rib's position allowed it to lend support to later magazines, such as Trouble and Strife (1983-2002), a radical feminist magazine, and the narrowly focussed Mukti (19831987), targeted at British Asian women. Its broad appeal meant it could also include ordinary women and professional writers, including those committed to other politics, such as socialism in the case of Sheila Rowbotham, and those who regularly wrote for established political magazines, including Beatrix Campbell who wrote for the influential Marxism Today (1957-1991). ${ }^{100}$ Spare Rib, then, offered a broad church of views: it was not as focussed as Red Rag (c.1973-1980), a more theoretically-oriented Marxist feminist magazine, but nor was it a commercialised glossy like Cosmopolitan (1972-ongoing), picking and choosing its way through female sexual liberation and feminist issues.

\section{Womens Voice}

Womens Voice (1972-1982), was one of the feminist magazines that emerged out of the socialist movement in Britain, from International Socialists (IS) and then the Socialist Workers Party (SWP). ${ }^{101}$ It flourished 1974-78, and summoned a thousand people in 1978 to a rally, ${ }^{102}$ yet had a mixed reception: seen by some as a financial burden on the party and by 
others as important for women socialists. Emerging from an established political movement and party organisation implies a different set of publishing processes and facilities, such as access to established publishers, typesetters etc., from the outset. It also implies accountability, and Womens Voice had an uncomfortable relationship with its parent organisation. Tony Cliff, SWP leader, had never really wanted the magazine, but was nervous about losing women activists. ${ }^{103}$ As the political commitment of Womens Voice grew closer to the newer feminist politics and priorities of the WLM, and attempted a more independent remit, the SWP became concerned that rather than bringing women into the SWP, Women's Voice was leading women out to the WLM. ${ }^{104}$ The history of the magazine's varied format indicates its uncertain position within the wider political group: it had an early precursor in 1970 as a newsletter by women members of the International Socialists who were 'surprised by the number of IS women that had found their way to the first Women's Liberation Conference, in February of that year', and five bulletins were produced over two years. In 1972 Womans Voice adopted a women's magazine style and changed its title slightly to Womens Voice. It established its own approach to feminist issues, taking its lead from the WLM, but offering a distinctively socialist perspective. Additionally, it established Womens Voice Groups, intent upon feminist grassroots activism. The format changed to a newspaper in 1974, but reverted to a magazine in 1977, starting at edition number one, and adopting a glossy appearance a year later. ${ }^{105}$ Whilst Womens Voice was financially supported and subsidised by the SWP, it was always contentious, as with women's relationship to socialism, ${ }^{106}$ and complaints developed about the financial burden of the magazine on SWP branches and the growing autonomy of the Womens Voice Groups. ${ }^{107}$ The groups were disbanded by the SWP leadership and Womens Voice ceased publication in 1982.

Womens Voice was politically resistant in tone from the outset, with many articles exposing social injustices against women. It particularly actively highlighted and supported 
working class and working women through articles about working and living conditions. An article about 'The Importance of Equal Pay' bemoans the lack of interest from the unions over this issue and categorically states that 'WOMAN'S VOICE [sic] thinks equal pay is very important'; moreover it calls on the unions to 'take women's interests seriously', with the strong implication that the TUC themselves were not giving women equal status. ${ }^{108}$ This was an anti-Tory and pro-working class values magazine for women who felt marginalised by British society, the class system and even by male-dominated left-wing organisations, with a broad appeal to women of colour and women working solely within the home, as well as hospital workers, cleaners, factory and shop workers. It was anti-Tory and pro-working class values. It was aware of women's working-class history, reprinting an article on the London 'Match Girls' strike of 1888, and other female working-class activism from Socialist Worker ${ }^{109}$ and an article on the working class relevance of first wave feminists: 'Sylvia Pankhurst and the East End Suffragettes’, encouraging its readers to continue the struggle against poverty. ${ }^{110}$ It was alive to sexism in the workplace, exploring the myth of the glamorous secretary and the reality of the regimented typing pool, ${ }^{111}$ and aware of the 'fairy story’ told of women’s lives in glossy magazines. ${ }^{112}$ Womens Voice had a more urgently political and left-wing feel than early Spare Rib, yet later similar outrage at women's place in society is expressed in both magazines. Despite early differences in tone, in a similar way to Shrew and Spare Rib, Womens Voice highlighted issues important to women such as abortion; persistently discussing the matter, exploring and explaining the legal position, exposing those who opposed giving full rights to women such as the proposed Corrie Bill and other attempts to reverse the 1967 Abortion Reform Act. It publicised individual causes and encouraged readers to write in with their personal stories, campaigns and journeys.

Womens Voice covered important social issues such as the Nestlé dried milk scandal and the sale of council houses, but also differed from other socialist magazines, and 
overlapped with Spare Rib, in that it tried to appeal to a wider female readership by including mainstream women’s magazines’ content with their focus on sex, diets and marriage. Concomitantly, it deliberately approached many of the same issues as other feminist publications, giving space to the impact of rape, contraception options, lesbianism, abortion, the problems with the Miss World competition. The magazine, also like Spare Rib, demonstrated direct engagement with feminist culture, for instance interviewing Marge Piercy after the publication of her feminist novels, as well as offering feminist-oriented interpretation of issues covered in the regular press, such as detailed coverage of the Northern Ireland troubles.

Like Shrew and Spare Rib, Womens Voice paid attention to Women's Liberation activism, but was less circumspect than Shrew. It encouraged activism and discussed how to establish Women’s Voice groups locally to encourage participation in politics and political resistance, such as establishing women's refuges. Information and skills were also imparted to readers through workshops on varied matters including printing posters and establishing rape crisis centres.

As well as evident engagement with feminist issues, Womens Voice firmly held to its socialist roots. It acknowledged its place within the world of publication by encouraging writing and publication within its readership, outlined how to write for the magazine and how to write industrial bulletins. Womens Voice encouraged women to tell their own stories, in their own words, and often these were augmented with images and commentary. Chris Atton has discussed how, in less centralist party-led forums, readers are encouraged to tell what they know. ${ }^{113}$ This mode was important in how Womens Voice established an identity: associated with the SWP, but also distinctly feminist-centred. The idea of 'native reporting' gave readers a sense of reliable witnesses telling their stories. ${ }^{114}$ One double-page spread contains an image of the letter written by Margaret Llywarch, wife of John Llywarch, a building worker, 
alongside a photograph of their family. Additionally an article expresses outrage at the treatment of building site strikers, charged with intimidation whilst picketing, in the 'Shrewsbury 24 ' case. ${ }^{115}$ This example of a male worker's story and the impact upon his family, told from the woman's perspective, combines a reader's letter with professional journalistic commentary to illustrate a wider set of working class and trade union issues. A complex position of feminist interpretation, socialist politics and trade union argument may be discerned here.

Later in the 1970s, an article by Lindsey German, 'Womens Voice: the way forward' makes clear both the relationship to the Socialist Workers Party and the difficulties inherent in that relationship. It describes how Womens Voice was launched in its present form in January 1977 by a group of women in the SWP, and how large numbers of women were becoming involved in political activism in the mid-seventies as a result of failure of laws to bring equality and welfare cuts:

The experience of working in these campaigns showed us that women were interested in SWP politics, particularly on issues that affect women directly. Womens Voice was launched as a way of introducing our political ideas to more women and drawing more women into political activity with us. ${ }^{116}$ The article continues explaining that magazine sales, Womens Voice meetings and Womens Voice Groups all grew rapidly. The argument was won within the SWP that, 'special forms of organisation are necessary to involve working class women, that we need Womens Voice to reach out specifically to women, and that we must deal with problems that affect us as women, as well as issues affecting the working class. ${ }^{117}$ However, problems arose, German continued, when women who were not members of the SWP became involved with Womens Voice magazine and groups, raising questions about the magazine's relationship with the Party. Some, it seemed, wanted to break with the SWP and build an 'active socialist feminist organisation'. ${ }^{118}$ Others wanted alignment with the SWP enabling work towards unification 
of all sectors of the working class, believing that 'socialism can only be achieved by the working class itself', and that remaining within the Party facilitated greater commitment to working towards socialist aims. An agreed statement was constructed to be 'adopted as our programme and should be on every Womens Voice card and in every issue of Womens Voice':

Womens Voice is an organisation that fights for Women's Liberation and Socialism. We fight for: equal pay, free abortion and contraception, maternity leave and child care provision, the right to work, against any form of discrimination of grounds of sex, sexual orientation or race. Womens Liberation is only possible through women organising and fighting for themselves. Womens Liberation can only be achieved by linking its struggles to those of the working class and overthrowing the capitalist system. Womens Voice supports the aims of the Socialist Workers Party. It is organisationally independent but based on the politics of the SWP. [sic] Slight variations of this statement appear on the inside back cover of each issue of the magazine. Whilst the statement clarified its affiliation to the SWP, it was the independent organisational aspects of the magazine, and the participation of non-Party member women, that were seen as particularly challenging to the existing SWP committee. Tony Cliff saw women's oppression only as part of the 'wider relations of class exploitation', ${ }^{119}$ and despite attempts to locate the magazine's outlook within the SWP's aims of liberation from capitalism, the feminist influence over the content and tone was ultimately seen as too removed from the Party. ${ }^{120}$ Alignment to existing socialist politics made it impossible for this feminist magazine, with its WLM leanings, to continue as an independent feminist production. Any advantages of party association in the production of the magazine were surely outweighed by the control exerted from that same quarter; something avoided by the determined political separatism of other WLM magazines. 


\section{Conclusion}

Shrew, Spare Rib and Womens Voice, all part of the same social movement, emerged from different publishing hinterlands. Feminist magazines were a significant portion of WLM print culture: educating and encouraging women in their fight for equality, circulating the meaning of second-wave feminism, raising consciousness and supporting activism. They brought new feminist ideas and female-centred modes of expression and resistance to their readerships, enabling women to experience activism, resonated with the WLM whilst developing their own politics. Feminist magazines took their place in wider print cultures too: borrowing styles from mainstream magazine formats and skills from the publishing industries, mimicking the satirical tones of the underground presses supporting other feminist magazines, and responding to mainstream press items. All whilst embracing new, less formal, modes of printed expression.

These three magazines, with similar ambitions and content, demonstrate three different approaches to the writing, construction and publication context of a WLM feminist magazine. Despite their overlapping causes, they each had a different set of engagements with the publishing industry, the WLM, their contributors, and with feminism. This resulted in quite different interventions and contributions to the movement. Shrew was defined by the very act of its assembly, purposefully drawing different groups, voices and perspectives together to create, construct and publish a feminist magazine. Spare Rib emerged out of counter-cultural publication know-how, and deployed those skills for a marginalised group, also inviting other women to write, but in a more mainstream manner than many other feminist magazines. Women's Voice grew from within an existing, theoretically sympathetic, political base, and showed women how to understand their position in society from a socialist perspective; what was less well defined, and accounted for, was the role of women within the socialist organisation. 
Feminist magazines were a means of teaching women to express themselves through publication and journalistic skills, permitting engagement in feminist activism and contributing to the movement through the very act of producing a magazine. By claiming this access to print cultures, as well as increased and enlarged involvement in all aspects of the print industry from typesetting to bookselling, women of all backgrounds and talents demonstrated the importance of print media and print cultures to the Women's Liberation Movement. 


\title{
Notes
}

\begin{abstract}
${ }^{1}$ Lynne Segal (2007) Making Trouble: Life and Politics ( London: Serpent’s Tail). Retrospective correspondence interview with Marsha Rowe, co-founder of Spare Rib, both quotations p. 109.

${ }^{2}$ This includes online magazines such as the F-word (www.thefword.org.uk); websites that invite contribution such as The Everyday Sexism Project (everydaysexism.com); the internet presence of feminist organisations such as the Fawcett Society and Southall Black Sisters; twitter feeds and much more all contribute to an ongoing discussion of twenty-first century feminism. Nonetheless, a fourth wave of feminism is contested: with some arguing that any fourth wave must be more than an online presence; and others arguing that there are increased opportunities for intersectionality, global campaigning and activism.

${ }^{3}$ Beatrix Campbell interviewed by Margaretta Jolly (2010) British Library C1420/01 Track 3.

${ }^{4}$ Sara Maitland, quoted in Segal, Making Trouble p.110.

${ }^{5}$ Sandra M. Gilbert \& Susan Gubar (1979) Infection in the Sentence: The woman writer and the anxiety of authorship, in Robyn R. Warhol \& Diane Price Herndl (Eds) (1997) $2^{\text {nd }}$ ed. Feminisms: An anthology of literary
\end{abstract} theory and criticism (New Brunswick, NJ: Rutgers University Press), pp. 21-32, 22.

${ }^{6}$ Trysh Travis (2008) The Women in Print Movement: History and Implications, Book History, 11, pp.275-300.

${ }^{7}$ Helen Graham (2003) ‘New' 1970: 'I', 'we’ and ‘anyone else,' in Helen Graham, Ali Neilson \& Emma

Robertson (Eds) The Feminist Seventies (York: Raw Nerve Books), pp.159-172, p.164.

${ }^{8}$ Jackie Stacey (2003) The Feminist Seventies, preface.

${ }^{9}$ Murray,Mixed Media, p.18. Murray also notes that this history was not chronicled by male historians, pp.1013.

${ }^{10}$ Trysh Travis 'The Women in Print Movement', p. 276 both quotations.

${ }^{11}$ Ann Feigenbaum (2013) Written in the Mud, Feminist Media Studies, 13:1, pp. 1-13. My emphasis.

${ }^{12}$ Also see Barbara Green (2012) Complaints of Everyday Life: Feminist Periodical Culture and

Correspondence Columns in The Woman Worker, Women Folk and The Freewoman, in Modernism/modernity, 19:3, pp. 461-485.

${ }^{13}$ For a discussion of the Australian WLM see: Susan Magarey (2014) Women's Liberation was a Movement,

Not an Organisation, Australian Feminist Studies, 29:82, pp. 378-390.

${ }^{14}$ Juliet Mitchell (1971) Woman's Estate (Harmondsworth: Penguin), pp. 59-60.

${ }^{15}$ For a discussion of earlier feminists' engagement with print, see Simone Murray (2000) "Deeds and Words":

The Woman’s Press and the Politics of Print, Women: A Cultural Review, 11:3, pp. 197-222.

${ }^{16}$ Simone Murray (2004) Mixed Media: Feminist Presses and Publishing Politics (London: Pluto), p. 41.

Murray quotes June Arnold (1976) Feminist Presses and Feminist Politics' Quest, A Feminist Quarterly, 3.1, pp.

18-26; and Charlotte Bunch (1977) Feminist Publishing an Antiquated Form? —Notes for a Talk at the Old

Wives Tales Bookstore, Heresies, 3, pp. 24-6.

${ }^{17}$ Murray, Mixed Media, p. 41.

${ }^{18}$ Murray, Mixed Media, p. 27. Original emphasis.

${ }^{19}$ Debbie Cameron \& Joan Scanlon (Eds) (2010) The Trouble \& Strife Reader (London: Bloomsbury

Academic), p. 8

${ }^{20}$ Trysh Travis (2008) The Women in Print Movement: History and Implications, Book History, 11, pp.275-300.

${ }^{21}$ Kate Adams (1998) 'Built out of Books, Journal of Homosexuality, 34:3-4, pp. 113-11.

${ }^{22}$ For example, Esmé Langley's difficulties printing the first editions of Arena Three, an early lesbian magazine, resulted in a home-produced roneoed version. See Laurel Forster (2015) Magazine Movements (London:

Bloomsbury), p. 92.

${ }^{23}$ Travis 'The Women in Print Movement' pp. 281-2.

${ }^{24}$ http://www.womeninpublishing.org.uk/about-us/ Last Accessed 8 August 2015. At the time of writing it still holds monthly meetings.

${ }^{25}$ Marsaili Cameron (1987) 'What the Hell is Feminist Editing?' in Gail Chester \& Sigrid Nielsen (Eds) In Other Words: Writing as a Feminist (London: Hutchinson), pp.119-125.

${ }^{26}$ Joy Pitman 'Why there's a light-box where my typewriter should be - being a feminist writer' in Chester \& Nielsen, In Other Words, pp. 104-108.

${ }^{27}$ Ellen Galford 'Working in the Word Factory' in Chester \& Nielsen, In Other Words pp. 89-92.

${ }^{28}$ Gail Chester (1996) Book Publishing - A Gentleperson's Profession?, in Sarah Richardson, Merylyn Cherry, Sammy Palfrey \& Gail Chester (Eds) Writing on the Line: 20th Century Working-Class Women Writers (London: Working Press). pp. 141-148.

${ }^{29}$ Shaila Shah 'Producing a feminist magazine' in Chester \& Nielsen, In Other Words, pp. 93-99.

${ }^{30}$ For instance, Adrian Bingham (2004) Gender, Modernity and the Popular Press in Inter-War Britain

(Oxford: Clarendon), notes that whilst many inter-war papers vilified feminists and feminism, others had a 
'coherent feminist perspective'(109), and that there was a more varied relationship to feminism than has been suggested.(246).

${ }^{31}$ Anna Coote \& Beatrix Campbell (1982) Sweet Freedom: The Struggle for Women's Liberation (Oxford:

Blackwell), p. 204; and Ch 7 for a discussion of the relationship between women and the media.

${ }^{32}$ Mitchell, Woman's Estate, p.44.

${ }^{33}$ David Bouchier (1984) The Feminist Challenge: The Movement for Women's Liberation in Britain and the USA (New York: Schocken Books), p.99.

${ }^{34}$ Bingham, Gender, Modernity and the Popular Press, p. 248.

${ }^{35}$ Kaitlynn Mendes (2011) Reporting the Women’s Movement, Feminist Media Studies, 11:4, pp. 483-498, p. 488.

${ }^{36}$ Mendes, 'Reporting the Women's Movement', p. 488.

${ }^{37}$ Mendes, 'Reporting the Women's Movement', p. 493.

${ }^{38}$ Mendes, 'Reporting the Women's Movement', p. 488.

${ }^{39}$ Elizabeth Nelson (1989) The British Counter-Culture 1966-73: A Study of the Underground Press

(Basingstoke: Macmillan), pp. 138-139.

${ }^{40}$ Nelson, British Counter-Culture, p. 139.

${ }^{41}$ Carol Mueller (1994) Conflict Networks and the Origin of Women's Liberation, in Vincent Ruggiero \&

Nicola Montagna, (Eds) (2008) Social Movements: A Reader (Abingdon, Oxon: Routledge), pp. 226-234, 230-1.

${ }^{42}$ Marsha Rowe (Ed) (1982) Spare Rib Reader (Harmondsworth: Penguin), p. 15.

${ }^{43}$ Rosie Boycott (1984) A Nice Girl Like Me (London: Chatto and Windus), p. 56.

${ }^{44}$ Boycott, Nice Girl, pp.56-57.

${ }^{45}$ Lynne Segal (2013) Feminist Impacts and Transformations, in Lawrence Black, Hugh Pemberton \& Pat

Thane (Eds) Reassessing 1970s Britain (Manchester: Manchester University Press), pp. 149-166.

${ }^{46}$ Also see Scanlan \& Cameron, Trouble \& Strife, p. 4, who make a similar comment about the contributors to Trouble and Strife.

${ }^{47}$ Rowe, Spare Rib Reader, p. 15; p .13.

${ }^{48}$ Rowe, Spare Rib Reader, p. 16.

${ }^{49}$ Murray, Mixed Media, p.213

${ }^{50}$ Ibid., p. 19.

${ }^{51}$ Ibid., p. 39.

52 Ibid., pp. 32-33

${ }^{53}$ Ibid., p. 32. (Emphasis in original)

${ }^{54}$ Attested by Mary Chamberlain at a Southampton University History seminar, Feminism in 1970s Britain: Society, Culture and Literature, (12 February 2014), whose book, Mary Chamberlain (1973) Fenwomen: A Portrait of Women in an English Village (London: Virago) was the first Virago publication.

${ }^{55}$ Catherine Riley (2014) "The Message is in the Book": What Virago's Sale in 1995 Means for Feminist Publishing, Women: A Cultural Review, 25:3, pp. 235-255, p. 240.

${ }^{56} \mathrm{http}: / /$ www.windycitymediagroup.com/lgbt/Feminist-Bookstore-News-closes/28678.html. Also see, Travis

'The Women in Print Movement', pp. 288-291.

${ }^{57}$ Kristen Hogan (2008) 'Women’s Studies in Feminist bookstores: “All the Women’s Studies women would come in”, Signs: Journal of Women in Culture and Society, 33:3, pp. 595-621, p. 595.

${ }^{58}$ Nancy Fraser (1992) Rethinking the Public Sphere: A Contribution to the Critique of Actually Existing Democracy, in Craig Calhoun (Ed.) Habermas and the Public Sphere (Cambridge, MA: MIT Press), pp.109-42, p. 124.

${ }^{59}$ Hogan, 'Women’s Studies', pp. 606-7.

${ }^{60}$ Ibid., p. 596.

${ }^{61}$ Guardian (23 October 2001).

${ }^{62}$ Jill Radford (1994) History of Women's Liberation Movements in Britain, in Gabrielle Griffin, Marianne Hester, Shirin Rai \& Sasha Roseneil (Eds) Stirring It: Challenges for Feminism, (London: Taylor and Francis), Ch 2, pp. 43-50. Also see http://www.octoberbooks.org/.

${ }^{63}$ Lucy Delap, 16 April 2015 'Bookshops and Women’s Liberation c1975-2001' seminar paper given at Institute of Historical Research, University of London, School of Advanced Study, Senate House.

${ }^{64}$ Delap, 'Bookshops and Women's Liberation'.

${ }^{65}$ Sheila Rowbotham (2013) Introduction: Beyond the Fragments (Third Edition) in Sheila Rowbotham, Lynne Segal \& Hilary Wainwright Beyond the Fragments: Feminism and the Making of Socialism (1979) (Pontypool, Wales: The Merlin Press), pp. 9-18.

${ }^{66}$ For a range of women's issues recorded in feminist magazines, see the use made of such testimony and letters in Sheila Rowbotham (1989) The Past is Before Us: Feminism in Action since the 1960s (London: Pandora).

${ }^{67}$ See The Feminist Library, London for a range of WLM magazines: http://feministlibrary.co.uk/ 
${ }^{68}$ Maria DiCenzo with Lucy Delap \& Leila Ryan (2011) Feminist Media History: Suffrage, periodicals and the public sphere (Basingstoke: Macmillan).

${ }^{69}$ Betty Friedan (1963) The Feminine Mystique (New York: Norton, 2001), Ch 2.

${ }^{70}$ For a range of women's issues recorded in feminist magazines, see the use made of such testimony and letters in Sheila Rowbotham (1989) The Past is Before Us: Feminism in Action since the 1960s (London: Pandora).

${ }^{71}$ Laurel Forster (2010) Printing Liberation: The Women's Movement and Magazines in the 1970s, in Laurel Forster \& Sue Harper (Eds) British Culture and Society in the 1970s: The Lost Decade (Newcastle: Cambridge Scholars Publishing), pp. 93-106.

72 Joanne Hollows (2013) Spare Rib, Second-Wave Feminism and the Politics of Consumption, Feminist Media Studies, 13:2.

${ }^{73}$ Jilly Boyce Kay (2013) Speaking Bitterness: Second-Wave Feminism, Television Talk, and the case of No Man’s Land (1973), in Feminist Media Histories, 1:2 (spring 2015), pp. 64-89, 82-3.

${ }^{74}$ Linda Gordon (2013) Socialist Feminism: The Legacy of the "Second Wave”, New Labour Forum, 22(3), pp. 20-28, p. 24.

${ }^{75}$ Cameron \& Scanlon, The Trouble \& Strife Reader, p. 3.

${ }^{76}$ Bouchier, The Feminist Challenge, p.100.

77 See respectively Shrew May 1971 3:4; Shrew 4:5; Shrew December 1971 3:9.

${ }^{78}$ See respectively Shrew April 1972 4:2; Shrew October 1973 5:4.

79 Shrew, Spring 1977, p. 2.

${ }^{80}$ Daniel Cohen, (2002) Feminist Theology, Men and the Goddess: Reminiscences and Opinions, Feminist Theology: The Journal of The Britain and Ireland School of Feminist Theology, 11, pp. 27-34.

${ }^{81}$ Deborah Knowles (2002) Asphodel Long: Contexts and Paradigms, Feminist Theology: The Journal of The Britain and Ireland School of Feminist Theology, 11, pp. 35-45.

82 Shrew, Spring 1977, p. 14.

${ }^{83}$ Daniel Cohen, 'Feminist Theology, Men and the Goddess', pp. 27-34.

${ }^{84}$ Shrew, Spring 1977, pp. 5-6.

${ }^{85}$ David Bouchier, The Feminist Challenge, p. 100.

${ }^{86}$ Graham, "New" 1970, p.159.

${ }^{87}$ Ibid., p. 163.

${ }^{88}$ Ibid., pp. 164-165.

${ }^{89}$ Ibid., p. 167.

90 Janice Winship (1987) Inside Feminist Magazines (London: Pandora), p. 123; Cameron \& Scanlon The Trouble and Strife Reader, p.4

${ }^{91}$ Winship, Inside Feminist Magazines.

${ }^{92}$ Laurel Forster (2014) Magazine Movements: Women's Culture, Feminisms and Media Form (London:

Bloomsbury), Ch 8

${ }^{93}$ See http://afonsoduarte.tumblr.com/post/538575214/interview-with-marsha-rowe.

${ }^{94}$ Joanne Hollows (2013) Spare Rib, Second-Wave Feminism and the Politics of Consumption, Feminist Media Studies, 13:2, pp. 268-287.

${ }^{95}$ Hollows, 'Spare Rib, Second-Wave Feminism and the Politics of Consumption', p. 273, 279.

${ }^{96}$ Boycott, Nice Girl, Ch 8.

${ }^{97}$ This resonates strongly with a current fourth wave of craftivism REF. Also see Rozsika Parker (1984) The

Subversive Stitch: Embroidery and the Making of the Feminine (London: The Women's Press).

${ }^{98}$ Rozsika Parker (1984) The Subversive Stitch: Embroidery and the making of the feminine (London: The Women's Press), pp. 205-210.

${ }^{99}$ See Winship, Inside Women's Magazines Ch 8 for further analysis of these changes.

${ }^{100}$ Marxism Today carried a debate about the relationship of 1970s feminism to socialism. See Tricia Davis and Catherine Hall (1980) The Forward Face of Feminism, Marxism Today (Oct 1980), pp. 14-16

101 Tony Cliff (2000) A World to Win: Life of a Revolutionary (London: Bookmarks Publications). Ian Birchall (2011) Tony Cliff: A Marxist for his Time (London: Bookmarks Publications).

102 For an overview of this magazine see: https://livesrunning.wordpress.com/2013/09/26/womens-voice-aretrospective/ Last accessed 1 November 2014.

${ }^{103}$ Ian Burchill, Tony Cliff, p. 466

${ }^{104}$ Sue Bruley (2014) Jam Tomorrow? Socialist Women and Women's Liberation, 1968-82: an oral history approach, in Evan Smith \& Matthew Worley (Eds) Against the Grain: The British Far Left since 1956

(Manchester: Manchester University Press), pp. 155-172, p. 165.

105 Womens Voice (January 1980), p. 28 (back page)

106 The difficulties of this relationship are discussed by Sheila Rowbotham (1979) The Women's Movement and Organising for Socialism, in Sheila Rowbotham, Lynne Segal \& Hilary Wainwright Beyond the Fragments: Feminism and the Making of Socialism, (2013) $3^{\text {rd }}$ edn (London: Merlin), pp. 125-240. 
${ }^{107}$ Bruley, 'Jam Tomorrow?' p. 165.

${ }^{108}$ Womens Voice, (November/December 1972), pp. 7-8.

${ }^{109}$ Womens Voice, (January/February 1973), p. 7.

${ }^{110}$ Womens Voice, 9July/August 1973), pp. 10-11. Also see 'Review: the Rights of Women by Mary

Wollstonecraft', Womens Voice( May/June 1973), p. 14.

111 'Goodbye to Costly Dolly Birds', Womens Voice, (May/June 1973), pp. 6-7.

112 'Behind the Glossy Pages',Womens Voice, (January/February 1973), p. 10.

${ }^{113}$ Chris Atton (2002) Alternative Media (London: Sage), p. 104.

114 Atton, Alternative Media, p. 112.

115 Womens Voice, (January 1973), pp. 8-9.

${ }^{116}$ Womens Voice, (November 1979), p.16. Emphasis in original.

${ }^{117}$ Ibid.

118 Ibid.

${ }^{119}$ Burchill, Tony Cliff, p.467.

${ }^{120}$ Lindsey German went on to be editor of Socialist Review (1978-2005; 2007-ongoing), from 1984 to 2004. 